\title{
PYROXENE AND AMPHIBOLE CHEMISTRY OF PERALKALIC ULTRA-POTASSIC SYENITE AND ASSOCIATED PYROXENITE, NORTHEASTERN BRAZIL: AN APPROACH TO TEST LIQUID IMMISCIBILITY PROCESS
}

\author{
VALDEREZP.FERREIRA* \& ALCIDES N. SIAL*
}

\begin{abstract}
RESUMO QUÍMICA DE PIROXÊNIOS E ANFIBÓLIOS DE SIENITOS PERALCALINOS ULTRAPOTÁSSICOS E PIROXENITOS ASSOCIADOS. NORDESTE DO BRASIL: UM MÉTODO PARA TESTAR O PROCESSO DE IMISCIBILIDADE DE LÍQUIDOS. Imiscibilidade de líquidos tem sido um processo pouco explorado como um dos mecanismos de geração de magmas de composição contrastante, embora sua importância tenha sido reconhecida em alguns plutões. Neste trabalho é discutida a química de fases máficas de sienitos ultrapotássicos e piroxenitos que coexistiram como líquidos por um certo período de tempo, no Batólito de Triunfo, Pernambuco. Os dois tipos de rochas têm as mesmas fases minerais (clinopiroxênio, microclina, apatita, titanita, anfibólio azul), apenas em quantidades diferentes. A química de piroxênio (aegirina-augita), que é apenas ligeiramente zonado, e anfibólio (richterita rica em K), mostra que essas fases no piroxenito são similares às suas correspondentes no sienito, havendo uma superposição composicional. Essa feição sugere fortemente equilíbrio químico entre o sienito e o piroxenito, uma das exigências para que dois líquidos constituam um par imiscível. Essa hipótese é apoiada pela presença de inclusões de rocha mista, que consiste de gotas centimétricas, quase arredondadas, de sienito e piroxenito mutualmente interticiais, numa textura semelhante à de emulsão, sendo um registro da divisão do magma.
\end{abstract}

Palavras-chaves: Imiscibilidade de líquidos silicáticos, química mineral, piroxenito, sienito ultrapotássico

\begin{abstract}
Liquid immiscibility has been a process little explored as a mechanism for generation of magmas of contrasting composition, although its importance has been recognized by some petrologists. In this work, the chemistry of mafic phases in ultrapotassic syenite and pyroxenite, which seem to have coexisted as liquids for a certain period of time, in the Late Precambrian Triunfo pluton, Pernambuco, is discussed. The two rock types have the same mineral phases (clinopyroxene, microcline, apatite, sphene, blue amphibole) only at different amounts. The chemistry of pyroxene (aegirine-augite), which is only slightly zoned, and amphibole (K-rich richterite) of both rock types, show that the mineral phases in the pyroxenite are similar to their corresponding ones in the syenite, compositionally overlapping. These features strongly suggest chemical equilibrium between syenite and pyroxenite, which is one of the requirements for two liquids constitute an immiscible pair. This hypothesis is supported by the presence of mixed-rock inclusions that consist of $\mathrm{cm}$ sized, near-rounded, syenitic and pyroxenitic drops mutually interstitial, in an emulsion-like texture, which record magma splitting.
\end{abstract}

Keywords: Silicate liquid immiscibility, mineral chemistry, pyroxenite, ultrapotassic syenite

INTRODUCTION Peralkaline intrusions of syenites are common in the Proterozoic Cachoeirinha-Salgueiro Foldbelt (CSF), northeast Brazil (Fig. 1). They vary from potassic to ultrapotassic (classification of Foley et al. 1987) silica-saturated to oversaturated syenites, quartz syenites and granites, forming stocks, dike sets, ring dikes and batholiths. The largest of the ultrapotassic ( $\mathrm{K}_{2} \mathrm{O}$ up $\left.12.8 \mathrm{wt} \%\right)$, silica-saturated plutons is the Triunfo batholith, which stands up to about $1.000 \mathrm{~m}$ above sea level, one of the highest elevations in the state of Pernambuco. The batholith occupies an area of about $600 \mathrm{~km}^{2}$, and is in contact with phyllites and biotite schists of the CSF and basement migmatites.

The main rock in the Triunfo Pluton is an alkali feldspar syenite which carries a large amount of pyroxenite which occurs as co-magmatic inclusions, syn-plutonic dikes and as late (brittle)-stage dikes. The contacts between host syenite and its pyroxenite co-magmatic inclusions are sharp, but the outlines are smooth. These field features are suggestive that most of the syenite and pyroxenite were liquid when they came into contact with each other. Besides, while coexisting as liquids, pyroxenite and syenite maintained no significant difference in temperature, as indicated by the lack of quench textures, such as needle-like apatite and finergrained grain size in the margins of the mafic phase.

Several lines of evidence indicate thermo-chemical equilibrium between the syenite and pyroxenite, which, in addition to the field relations, suggest that they were formed through a liquid immiscibility process (Ferreira et al. 1992).
This hypothesis is supported by the presence of inclusions of a "mixed" rock, which presents emulsion-like texture, suggestive they may represent part of the original magma before splitting.

This paper describes the chemistry of green clinopyroxene and blue amphibole of the syenite, pyroxenite and mixed rock of the Triunfo batholith, that indicates chemical equilibrium between the three rock types, therefore, compatible with the hypothesis of liquid immiscibility.

PETROGRAPHY Syenite Detailed petrographic description of the Triunfo batholith is given by Ferreira et al. (1992) and only a brief account is presented in this paper.

The Triunfo pluton, in spite of its huge volume, is principally composed of rocks with uniform texture and simple mineralogy. They are mostly equigranular, medium-grained leucocratic alkali feldspar syenites, in which feldspar and clinopyroxene rarely exceed a few millimeters. The majority of samples examined do not contain modal quartz, and syenites are silica-saturated to slightly oversaturated, usually containing normative nepheline, although modal feldspathoid is not observed.

The rocks are predominantly composed of microcline and aegirine-augite, with variable proportions of quartz, sphene, apatite, blue amphibole and magnetite (Photo 1). Tiny brown mica is present in some places. Microcline is the most abundant mineral, corresponding to about 80 volume $\%$ of the rock. It occurs as subhedral to anhedral 


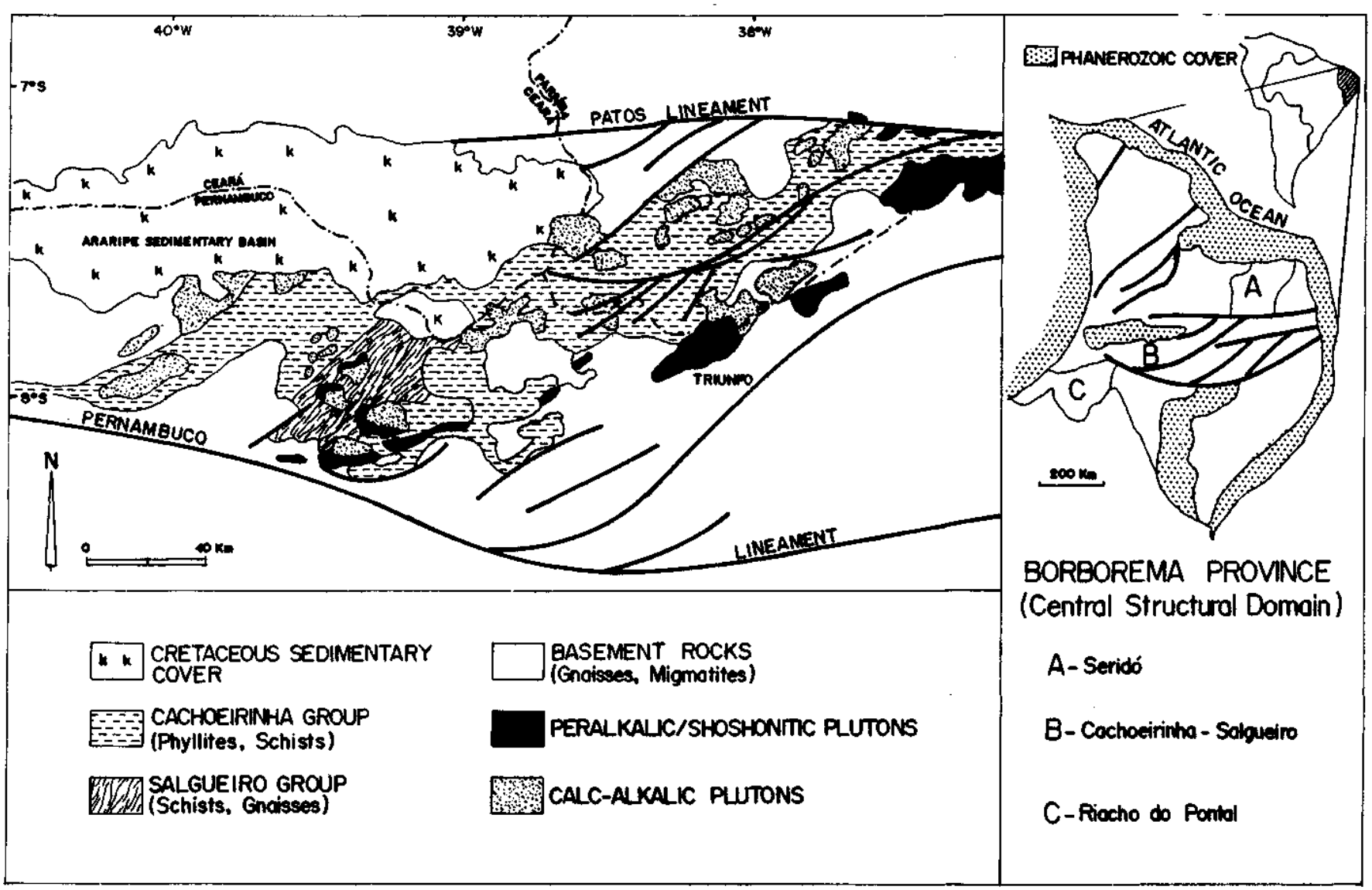

Figure 1 -Location of the Triunfo Batholith, on the southern boundary of the Cachoeirinha-Salgueiro Foldbelt, northeastern Brazil. Sketch of the geological map after Ferreira et al. (1992)

Figura 1 - Localização do Batólito de Triunfo, no limite sul do Cinturão de Dobramentos Cachoeirinha-Salgueiro, nordeste do Brasil. Esboço do mapa geológico é de Ferreira et al. (1992)

crystals, usually $0.1-$ to $2 \mathrm{~cm}$ long, showing grid twinning and, rarely, Carlsbad and grid twinning in the same crystal. Some of the feldspar grains are perthitic, containing vein and film albite exsolutions. Deuteric activity is suggested in some samples by the presence of quartz and untwinned albite along feldspar boundaries. Euhedral clinopyroxene, apatite and sphene crystals are sometimes enclosed by feldspar.

Aegirine-augite occurs as green subhedral to euhedral crystals with deep to pale green pleochroism. Most crystals are a few millimeters in size, but some are up to $1 \mathrm{~cm}$, in the coarser-grained rock types. Some crystals have simple twinning. In most exposures, pyroxene grains are aligned, locally forming clots parallel to the mineral lineation. Potassium-rich richterite is intimately associated with the pyroxene, formed along its cleavages or as rims and partial rims, together with small subhedral to anhedral magnetite grains. Sphene and apatite are common inclusions within clinopyroxene.

Among the accessory minerals, sphene is the most abundant. It occurs as euhedral crystals in variable size from microscopic crystals enclosed by pyroxene and feldspar, to millimeter-sized crystals visible with the naked eye. Euhedral apatite is usually smaller or equal in size to the sphene. Biotite occurs sporadically, usually as small, subhedral crystals associated with the clinopyroxene.

Pyroxenite Numerous alkalic pyroxenite inclusions are observed throughout the Triunfo batholith, varying in shape and size from a few centimeters to 1 meter, oriented parallel to the flow foliation of the host syenite. In some places inclusions are plastically folded. Frequently they are more or less elongate, irregular to oval-shaped, with sharp contacts against the host syenite, but smooth outlines (Photo 2). Synplutonic (Photo 3 ) as well as late-stage (Photo 4) pyroxenite dikes in the syenite are usually up to $4 \mathrm{~m}$ long and up to 0.20 $\mathrm{m}$ wide. Within them, pyroxene grains have random distribution. They have about the same grain size as that in the host syenite, consisting mostly of subhedral to euhedral aegirineaugite ( $>90 \%$ volume), and sphene and apatite in variable amount (Photo 5). Blue amphibole occurs in frequently replacing pyroxene along rims. Microcline and interstitial quartz, although rare, are also observed in some samples.

Mixed rock Inclusions of a "mixed" rock are sometimes found in the Triunfo pluton. They vary in size from about $10 \mathrm{~cm}$ to up to $50 \mathrm{~cm}$, and have sharp to gradual contacts, but smooth outlines, with the host syenites. As a whole, this rock has a mafic syenitic composition, but actually it consists of syenitic and pyroxenitic material in an "emulsion"-Like texture, i.e. small, cm-sized, irregular to rounded drops mutually interstitial (Photo 6). The syenite and pyroxenite in these inclusions have the same mineral phases as the host syenites and pyroxenitic inclusions and dikes (aegirine-augite, microcline, apatite, sphene, blue amphibole), in textural relationships also similar to those in the rocks.

MINERAL CHEMISTRY The major mafic phases present in these rocks were analyzed by electron microprobe 


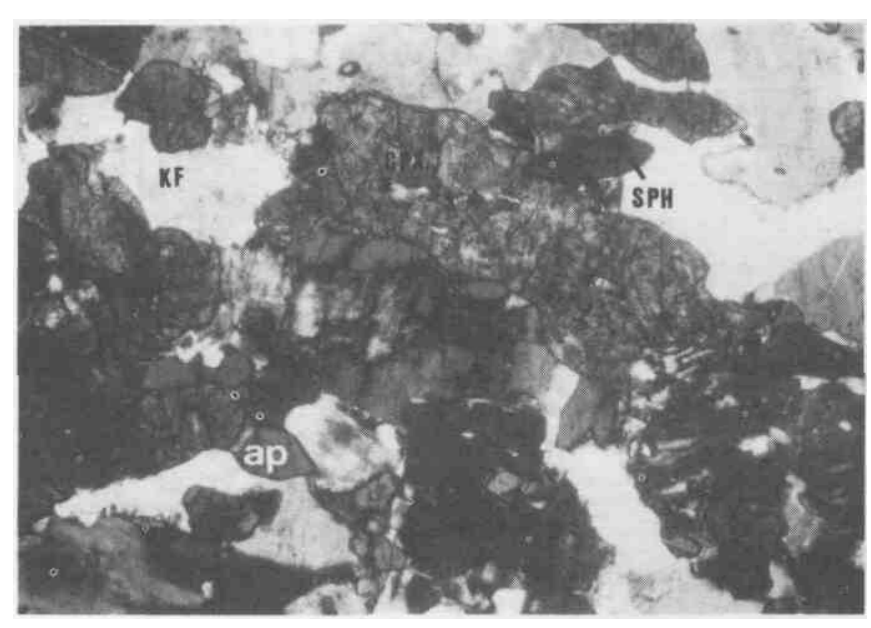

Photo 1- Photomicrograph of the Triunfo Syenite, presenting microcline as the main phase(Kf), aegirine augite(cpx), apatite (ap), and sphene(sph). The pyroxene grain shown is $1 \mathrm{~mm}$ long. (Crossed nicols)

Foto 1- Fotomicrografia do Sienito de Triunfo, mostrando microclina como fase mineral principal (kf), aegirina-augita (cpx), apatita (ap) e titanita (sph). O maior grão de piroxênio mostrado tem $1 \mathrm{~mm}$ de comprimento. Nicóis cruzados

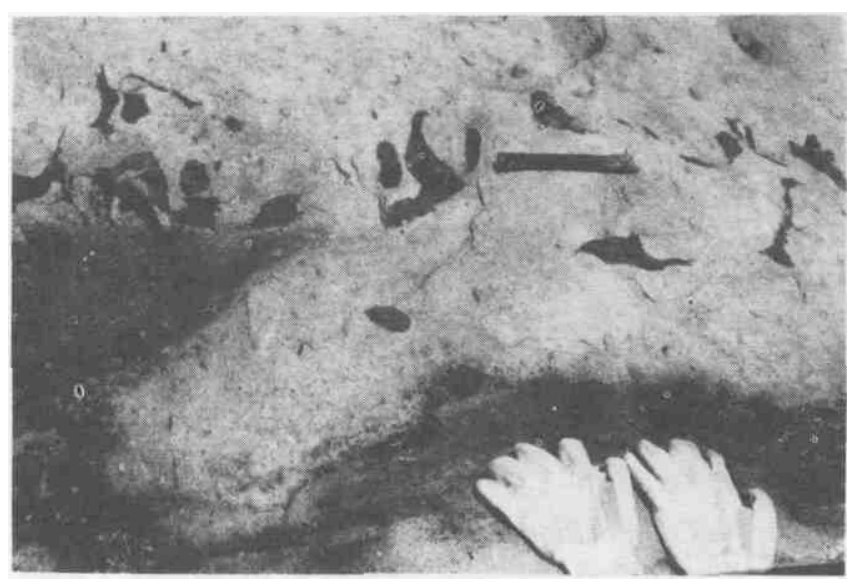

Photo 2 - Co-maginatic inclusions of pyroxenite in the Triunfo Syenite. In this example, the largest oftlie inclusions is about $20 \mathrm{~cm}$ long

Foto 2 - Inclusões co-magmáticas de piroxenitos no Sienito de Triunfo.

Neste exemplo, a maior das inclusões tem cerca de $20 \mathrm{~cm}$ de comprimento

to determine the chemistry of the original magma and to understand the processes and partition of elements that occurred during its evolution, as well as to evaluate the hypothesis of liquid immiscibility.

Most of the compositions of minerals of interest were determined for their major elements with a three-spectrometer Applied Research Laboratory model EMX electron microprobe, equipped with a wavelength dispersive system (WDS) and interfaced with an Apple microcomputer, at the Department of Marine, Earth and Atmospheric Sciences (MEAS), North Carolina State University, Raleigh, USA. In addition, some analyses were done at the Department of Geology, University of Georgia, USA, using a JEOL-JXA8.600 electron microprobe. The majority of the selected grains were analyzed at the core and edge and some of them at intermediate positions between the core and rim. Most points were analyzed twice and averaged.

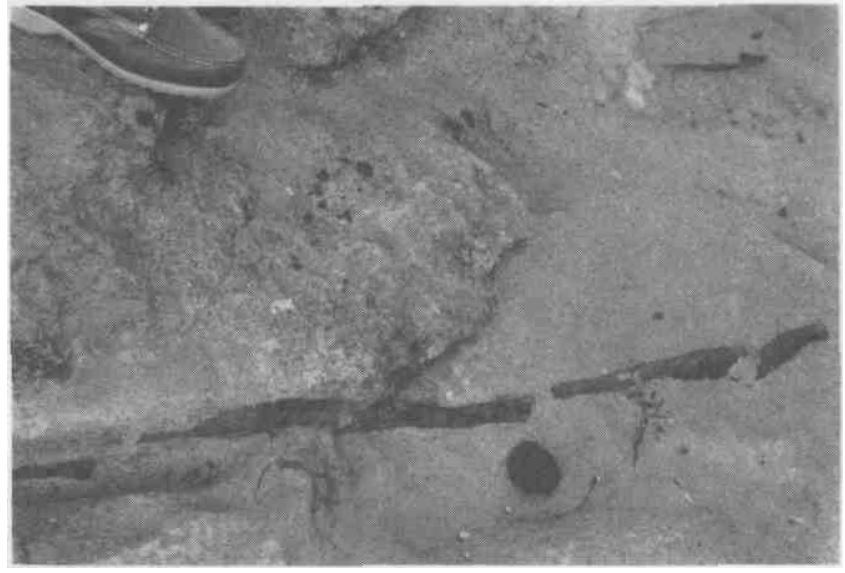

Photo 3 - Typical syn-plutonic pyroxenitic dike in the Triunfo Syenite, indicative of the coexistence of these two contrasting magma compositions

Foto 3 - Dique piroxenítico típico, sin-plutônico, no Sienito de Triunfo, indicativo da coexistência desses deis magmas de composição contrastante

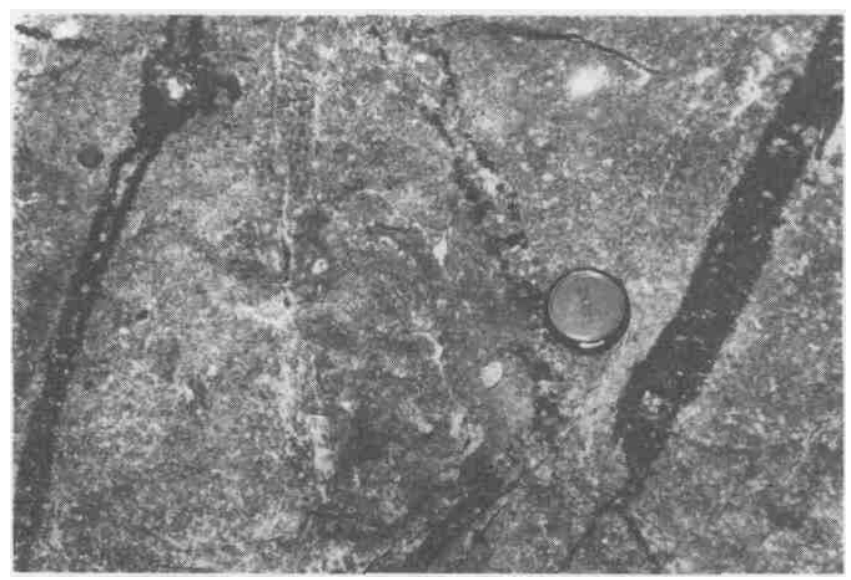

Photo 4 - Late-stage pyroxenitic dike cutting the Triunfo Syenite

Foto 4 - Dique de piroxenito tardio cortando o Sienito de Triunfo

For the analyses done at North Carolina, an augite sample from the Smithsonian Institute was used as standard except for K, for which a microcline sample, also from the Smithsonian Institute, was used. Elements were analyzed with LIF, TAP and PET crystals. For all analyses, the following parameters were maintained: accelerating potential: $15 \mathrm{kV}$; beam current: $135 \mu$. A; sample current: $0.4 \mu \mathrm{A}$; filament current: $1.64 \mu \mathrm{A}$; counting time: $10 \mathrm{~s}$.

For analyses done at UGA, except for the beam current $(15 \mu \mathrm{A})$ and accelerating potential $(15 \mathrm{kV})$ all the other operating parameters were identical to those used at MEAS.

Computer programs corrected the X-ray intensities for deadtime, background, mass absorption, fluorescence and atomic number. The technique described by Bence \& Albee (1968) and Albee \& Ray (1970) was used to calculate matrix corrections and to convert the data to weight percent oxides and atomic proportions. Cation proportions for the mineral formulae were calculated with the MINFILE program (Afifi $\&$ Essene 1988), on the basis of 6 oxygens for pyroxenes and 23 oxygens for amphiboles. Representative chemical compositions and mineral formulae are shown in tables 1 and 2 for pyroxenes and amphiboles, respectively. 


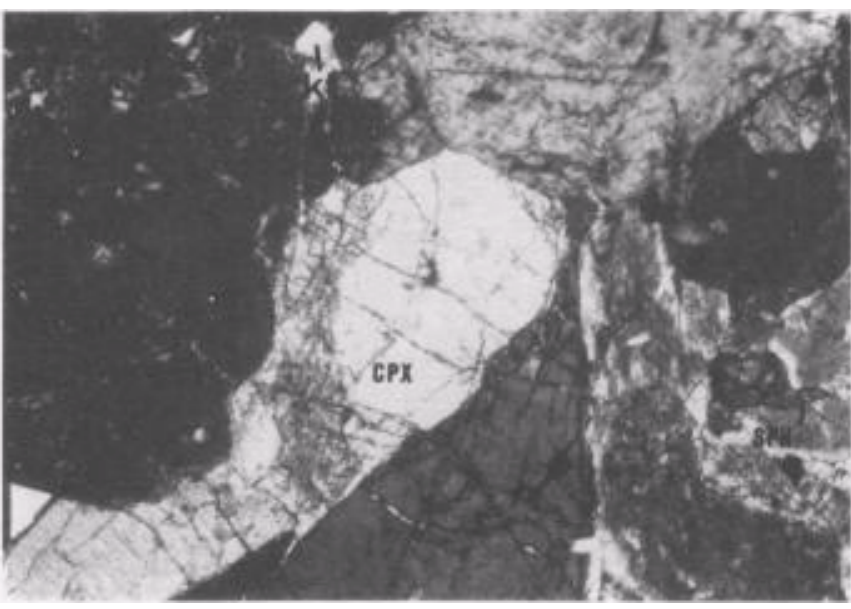

Pholo 5 - Photomicrograph of typical pyroxenite in the Triunfo Syenite, showing aegirine augite (1 nun long) (cpx), sphene (sph), and interstitial microcline (Kf). (Crossed nicols)

Foto 5 - Fotomicrograria de urn piroxenito típico no Sienito de Triunfo, mostrando aegirina-augita (de $1 \mathrm{~mm}$ de comprimento) (cpx), titanita (sph) e microclina intersticial (kf). Nicóis cruxados

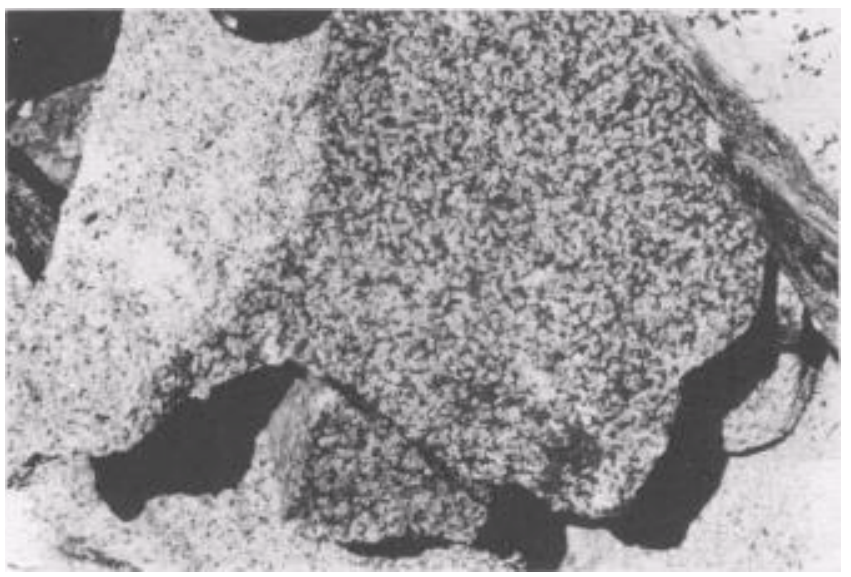

Photo 6- Mixed rock in the Triunfo Syenite. Rounded, cmsized light material lias syenitic composition, in contrast with the dark, interstitial material, which is pyroxenitic in composition

Foto 6 - Rocha mista no Sienito de Triunfo. O material claro, quase arredondado, centimétrico, tem composição sienítica, em contraste com o material escuro, intersticial, que tem composição piroxenítica

$\mathrm{Fe}^{3+}$ values of pyroxene were calculated assuming $\mathrm{Fe}^{3+}$ $(\mathrm{VI})=\mathrm{Al}(\mathrm{IV})+\mathrm{Na}\left(\mathrm{M}_{2}\right)-\mathrm{Al}(\mathrm{VI})-2 \mathrm{Ti}^{4+}(\mathrm{VI})$, according to the method described by Lindsley \& Anderson (1983). Proportions of ferric and ferrous iron for amphibole were estimated based on the procedure adopted by Robinson et al. (1982).

Pyroxene Compositions of green pyroxene occurring in the syenite, pyroxenite and mixed rock overlap. The chemistry of the pyroxene can be illustrated using diagrams of the figures 2 through 4 . Both core and rim of the pyroxene for the three rock types are calcic-sodic aegirine-augite according to Morimoto's (1988) nomenclature (Fig. 2) and form a trend from the augite to the ferroaugite fields in the quadrilateral of pyroxenes (Fig. 3).

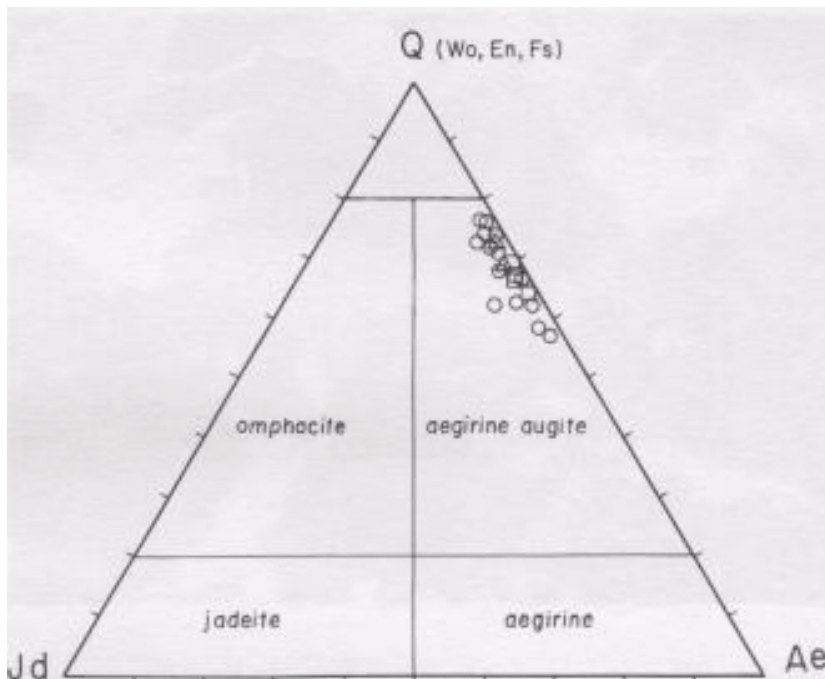

Figure 2 - Compositional variation of clinopyroxene of the Triunfo Batliolith in the Jd-Q-A diagram. Fields and nomenclature after Morimoto (1988). Symbols: circle = syenite; square = pyroxenite; triangle $=$ mixed rock Figura 2 - Variação composicional de clinopiroxênio do Batólito de Triunfo no diagrama Jd-Q-A. Os campos e nomenclatura são de Morimoto (1988). Símbolos: círculo sienito; quadrado piroxenito; triângulo rocha mista

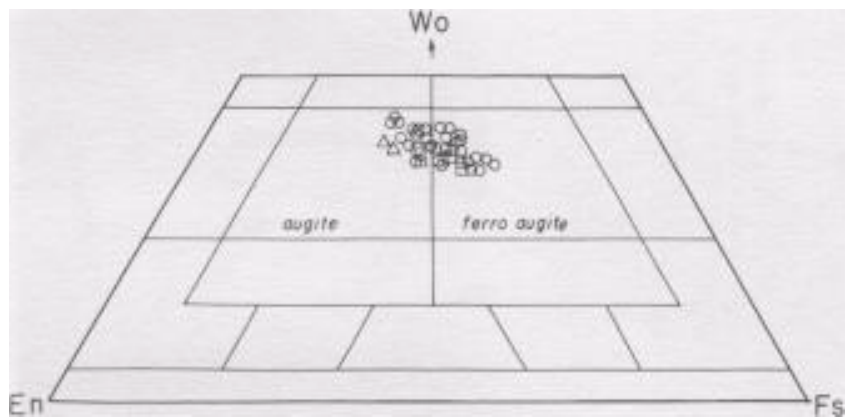

Figure 3-Compositional variation of clinopyroxene of the Triunfo Batholith in the quadrilateral of pyroxenes. Fields and nomenclature are the one adopted by Deer et al. (1978). Symbols as in figure 2

Figura 3 -Variação composicional do clinopiroxênio do Batólito de Triunfo no quadrilátero dos piroxênios. Os campos e nomenclatura são os adotados por Deer et al. (1978). Os símbolos são os mesmos da figura 2

Pyroxene trend is characterized by a progressive enrichment in $\mathrm{Na}$ towards the aegirine corner, with no significant enrichment in hedenbergite, in the diopside-heden ergiteacmite diagram (Fig. 4). The overall pyroxene trend is suggestive that fractionation involved a late, progressive increase in $\mathrm{Na}$, in a reaction of the type $\mathrm{Ca}^{2+}+\mathrm{Mg}^{+}+\mathrm{Fe}^{2+}$ $\mathrm{Na}^{+}+\mathrm{Fe}^{3+}$. This early trend of $\mathrm{Na}$ enrichment with the generation of aegirine-augite pyroxenes is probably a function of already enhanced alkali contents of the original liquid, associated with high oxygen fugacity conditions of the magma above the fayalite-magnetite-quartz (FMQ) buffer, as observed by Platt \& Wooley (1986) for peralkaline syenites in Malawi. Oxygen fugacity conditions above the FMQ in these rocks are also indicated by the presence of primary sphene.

In the three rock types, pyroxene is silica-saturated, precluding any significant substitution in the tetrahedral sites. 




Figure 4 - Compositional variation of pyroxenes of the Triunfo Pluton in the Di-Ac-Hd diagram. Compositional trend from Itapirapua (Gomes et al. 1970) is shown for comparison. Symbols as in figure 2

Figura 4 - Variação composicional do piroxênio do Plutão de Triunfo no diagrama Di-Ac-Hd. O trend composicional de Itapirapuã e de Gomes et at. (1970), mostrado para comparação. Os simbolos sao os mesmos da figura 2

The $\mathrm{A}_{2} \mathrm{O}_{3}$ content is uniformly low $(0.2-1.4 \%)$, a condition more typical of silica-oversaturated than of silica undersaturated syenite complexes (Platt \& Wooley 1986). Lack of Al-enrichment suggests that pyroxenes crystallized under relatively low pressure.

Uniform pleochroic green from core to rim is more common, but some compositional zoning within individual grains is indicated by medium- to pale-green cores and darker green rims. Zoning is well illustrated using the parameter $\mathrm{Na}-\mathrm{Mg}$ (atomic proportions) as fractionation index, as pyroxene is calcic-sodic, with $\mathrm{Mg}$ decreasing while $\mathrm{Na}$ increases during differentiation. Using this index, it can be seen that pyroxenes of the three rock types display similar compositions and trends of evolution, within individual grains and on the whole, with a compositional overlap. Both core and rim of pyroxenes are acmitic in composition with the maximum degree of Na-enrichment at the rims of individual grains, as expected in the evolution of peralkalic liquids.

$\mathrm{Na}-\mathrm{Mg}$ vs. $\mathrm{Fe}^{3+}$ (Fig. 5a) and $\mathrm{Na}-\mathrm{Mg}$ vs. Ca (Fig. 5b) plots reveal a slight but normal zoning, as $\mathrm{Fe}^{3+}$ and $\mathrm{Na}$ increase towards the rims of individual crystals and $\mathrm{Ca}$ and $\mathrm{Mg}$ decrease. Variations within individual grains are not pronounced, about 0.2 atomic proportions for both $\mathrm{Ca}$ and $\mathrm{Fe}^{3+}$, suggesting that fractional crystallization was rather restricted. Zoning apparently is not associated with variations in $\mathrm{Si}$, which is saturated in all cases, and in $\mathrm{Al}$ and $\mathrm{Ti}$, which are uniformly low.

The overall pyroxene compositional trend of the Triunfo Batholith differ from the pyroxene trend of the Roman province, Italy, Toro-Ankole, Uganda, and Leucite Hills, USA, representative of the three groups of ultrapotassic rocks, as defined by Fowley et al. (1987). Differences can be illustrated in terms of $\mathrm{Al} v s . \mathrm{Mg} /(\mathrm{Mg}+\mathrm{Fe})$ and $\mathrm{Na} v s . \mathrm{Mg} /$ $(\mathrm{Mg}+\mathrm{Fe})$ correlations (Figs. 6a and $\mathrm{6b})$. Although there are some differences in terms of $\mathrm{Al}$ and $\mathrm{Na}$ contents among

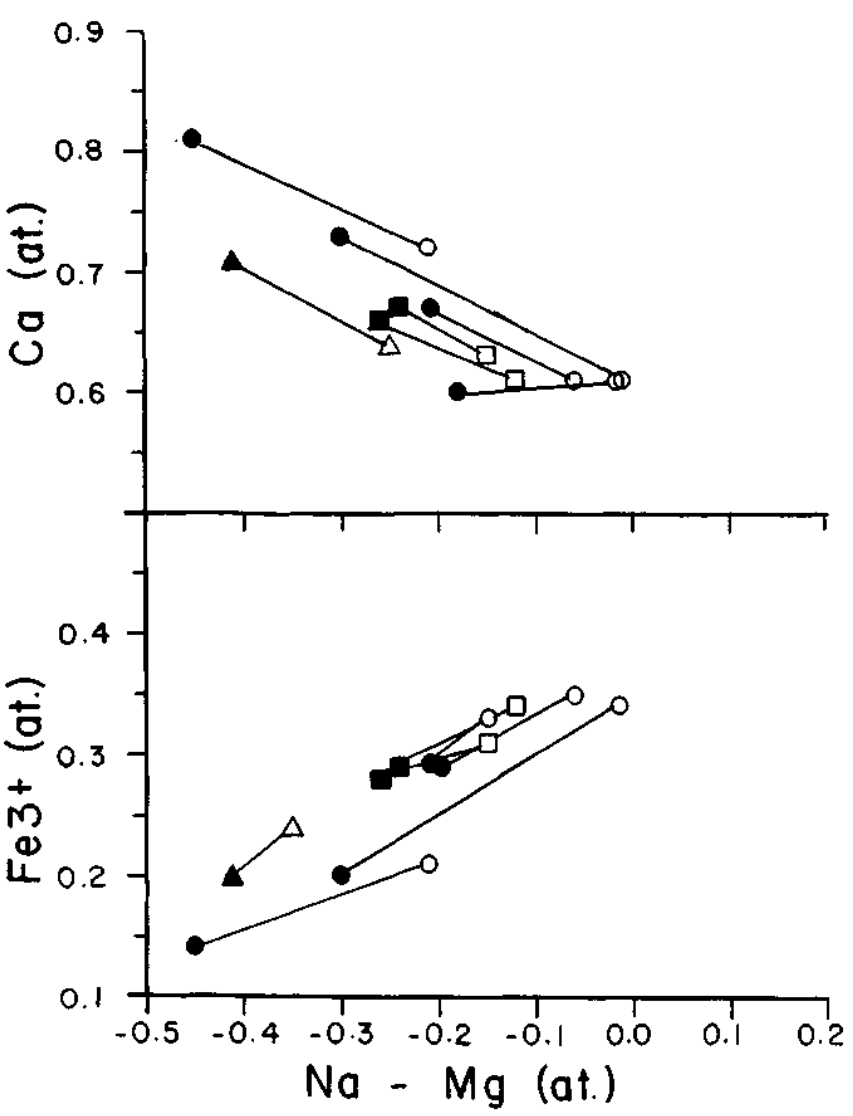

Figure 5 -Na-Mg (at. prop.) vs. Ca (at. prop.) (a) and $\mathrm{Na}-\mathrm{Mg}$ (at. prop.) vs. $\mathrm{Fe}^{3+}$ (at. prop.) (b) plots for clinopyroxene of the Triunfo Batholith. Symbols as in figure 2; open=rim; filled $=$ core Figura 5 - Diagramas $\mathrm{Na}-\mathrm{Mg}$ (prop, at.) vs. $\mathrm{Ca}$ (prop, at.) e $\mathrm{Na}-\mathrm{Mg}$ (prop, at.) vs. $\mathrm{Fe}^{3+}$ (prop, at.) para clinopiroxênio do Batólito de Triunfo. Símbolos são os mesmos da figura 2; os abertos referem-se aos bordos dos cristais, os fechados, aos núcleos

pyroxenes of those three groups, Triunfo pyroxenes are by far Al-poorer and Na-richer than any of the rest. Apparently, Al content is not correlated with degree of differentiation in the Triunfo pluton; there is a sharp increase in $\mathrm{Na}$ content with increasing total iron and an overall relative iron enrichment, a behavior not observed in the pyroxenes of those ultrapotassic rocks.

Amphibole All analyzed amphiboles are characterized by high $\mathrm{SiO}_{2}$, low $\mathrm{Al}_{2} \mathrm{O}_{3}$ and $\mathrm{TiO}_{2}$ contents, and low $\mathrm{MgO} / \mathrm{FeO}^{*}$ ratios" $\mathrm{K}_{2} \mathrm{O}$ content is relatively high (all values $2 \mathrm{wt} \%$ ) constituting $43-56 \%$ of total alkali in the A-site of the amphibole structure. As expected for highly alkaline rocks, the A site of the amphibole structures of the Triunfo rock types is highly occupied, always $>82 \%$, with $(\mathrm{Na}+\mathrm{K})$ varying 1.70-1.84 (atomic proportions).

Except for a slight decrease in $\mathrm{FeO}^{*}$ from core to rim, chemical zoning was not detected in any of the grains analyzed. The amphiboles from syenite, pyroxenite and mixed rock are potassium-rich richterite, according to Leake's classification (1978) (Fig. 7). They are compositionally similar to amphiboles from typical differentiated peralkaline suites, such as those from the Rallier-du-Baty Peninsula, Kerguelen (Maret \& Zimine 1976, apud Giret et al. 1980). Amphiboles from differentiated alkaline rocks evolve from barroisite to katophorite, to winchite, to richterite and, lastly, to arfvedsonite, involving $(\mathrm{K}, \mathrm{Na})^{\mathrm{A}} \mathrm{Fe}^{2+} \mathrm{Fe}^{3+}$ substitution, under reducing conditions (Giret et al. 1980). These authors noted that there is a close relationship between amphibole compo- 


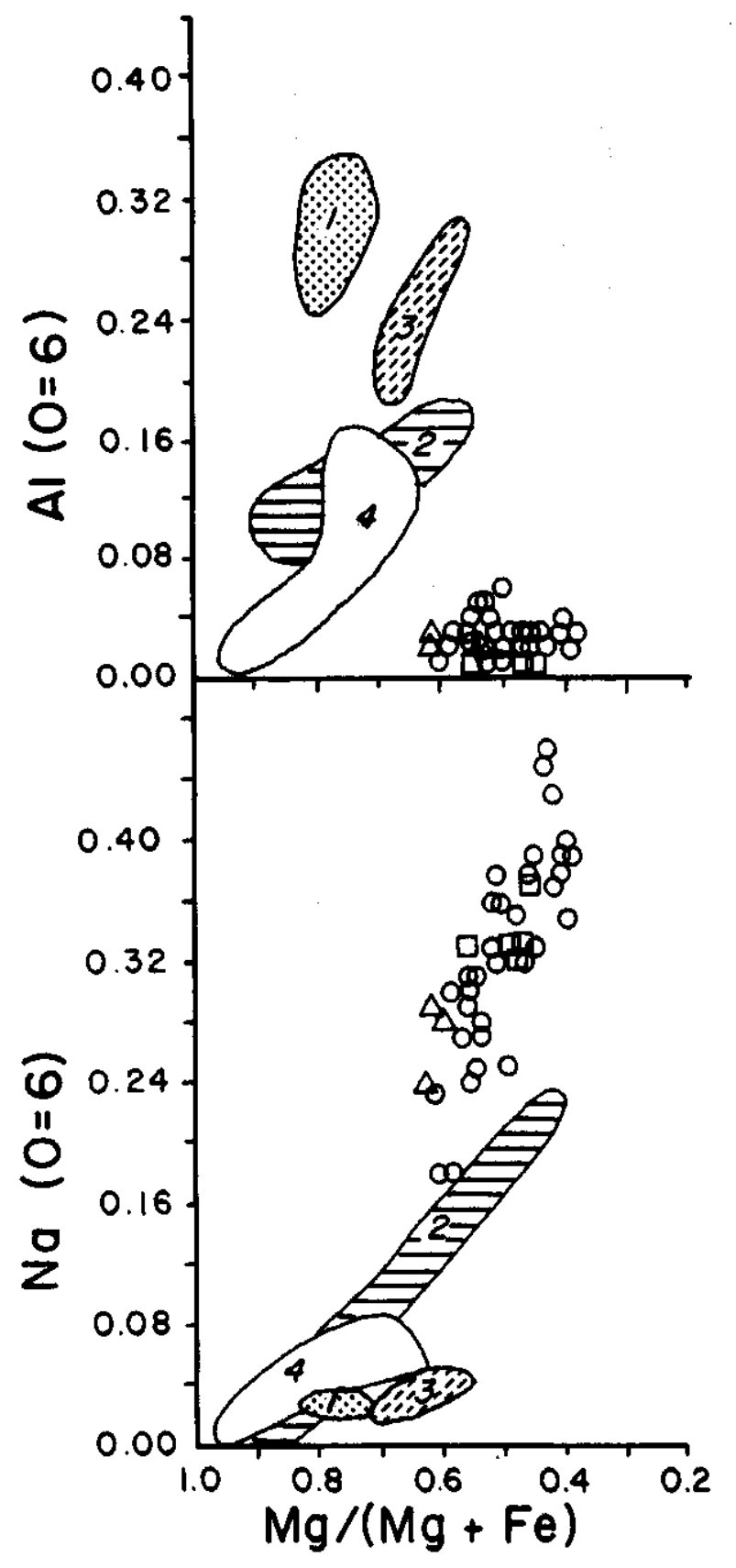

Figure 6 - Mg number vs. Al (at. prop.) (a) and Mg number vs. Na (at. prop.) (b) plots for clinopyroxenes of the Triunfo batholith. Compositional field for Somma-Vesuvius (field I) is based on analyses from Rahman (1975); fields for ToroAnkole (2), Vico (3) and Leucite Hills (4) are based on analyses from Barton (1979). Symbols for the Triunfo Pluton as in figure 2

Figura 6 - Diagramas número de $\mathrm{Mg} v s$. $\mathrm{Al}$ (a) e número de $\mathrm{Mg} v s$. Na para clinopiroxênios do Batólito de Triunfo. O campo composicional para Somma-Vesúvio (campo 1) é baseado em analises de Rahman (1975); os campos para Toro-Ankole (2), Vico (3) e Leucite Hills (4) são baseados em análises de Barton (1979). Símbolos são os mesmos da figura 2

sitional trends and agpaitic coefficient of their host rocks: the more differentiated the magma, the more silica-rich the amphiboles. According to them, these silica- and alkali-rich amphiboles crystallize only in a very late magmatic stage, usually later than alkali feldspar, or during hydrothermal stages. The amphibole compositions from the three Triunfo rock types plot in the field of amphiboles from differentiated alkaline rocks (Figs. 8 and 9), as would be expected for rocks derived from these rather evolved magmas, and in agreement with the conclusion of the latter authors. Amphiboles from the pyroxenites plot off-scale in Fig. 9 simply because the agpaitic index displayed by these rocks $(>10)$ is high. Amphiboles from the mixed rock plot outside the field for typical amphiboles of alkalic rocks as delimited by Giret et al. 1980, due to the very high agpaitic index of this rock, which contains about $40 \%$ of pyroxenite mixed with syenite.

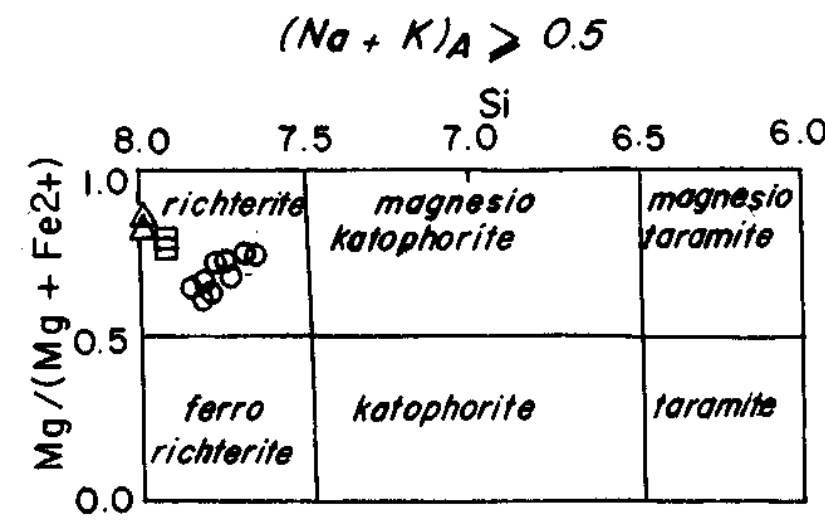

Figure 7- Amphibole compositions of the Triunfo Pluton, according to Leake's classification (1978). Symbols as in figure 2

Figura 7- Composição de anfibólio do Plutão de Triunfo, de acordo com a classificação de Leake (1978). Símbolos são os mesmos da figura 2

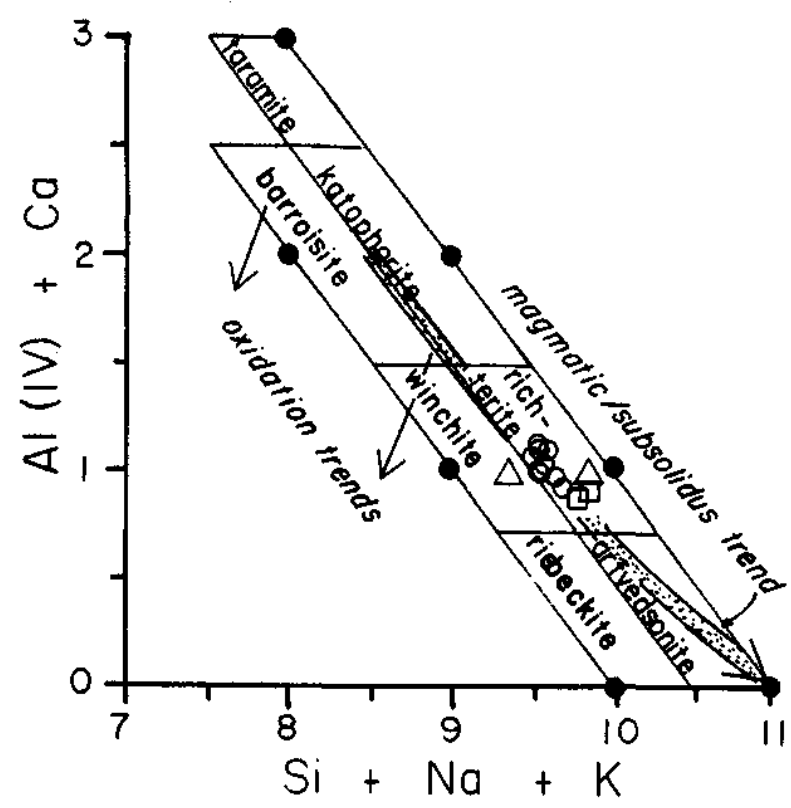

Figure 8-(Si+Na+K) (at. prop.) vs. $\left(A l^{I V}+\mathrm{Ca}\right)$ (prop, at.) diagram for amphibole of the Triunfo Batholith. General formulae and terminology after Leake (1978); field boundaries according to Giret et al. (1980). Symbols as in figure 2 Figura 8 -Diagrama ( $\mathrm{Si}+\mathrm{Na}+\mathrm{K})$ (prop, at.) vs. $\left(\mathrm{Al}^{\mathrm{IV}}+\mathrm{Ca}\right.$ ) (prop, at.) para anfibólio do Batólito de Triunfo. As fórmulas e terminologia são de Leake (1978); campos são de acordo com Giret et al. (1980). Símbolos são os mesmos da figura 2 
Table 1 - Representative chemical compositions and mineral formulae of pyroxenes of the Triunfo Batholith, northeastern Brazil-Proportions of ferric and ferrous iron were estimated based on the method by Lindsley \& Anderson (1973)

Tabela 1 - Composições químicas e fórmulas minerais representativas de piroxênios do Batólito Triunfo, Nordeste do Brasil. Proporções de ferro (III) e ferro (II) foram estimadas com base no método de Lindsley \& Anderson (1973)

\begin{tabular}{|c|c|c|c|c|c|c|}
\hline \multirow{2}{*}{$\begin{array}{l}\text { sample } \\
\text { point }\end{array}$} & \multicolumn{2}{|c|}{ TRF $=28$} & \multicolumn{2}{|c|}{ PTR-28 } & \multicolumn{2}{|c|}{ MTR-28 } \\
\hline & $r$ & c & $\mathbf{r}$ & c & $\mathbf{r}$ & c \\
\hline $\mathrm{SiO}_{2}$ & 52,40 & 52,50 & 52,60 & 53,30 & 53,50 & 54,20 \\
\hline $\mathrm{TiO}_{2}$ & 0,20 & 0.50 & 0,20 & 0,40 & 0,40 & 0,20 \\
\hline $\mathrm{Al}_{2} \overline{\mathrm{O}}_{3}$ & 0,60 & 0,40 & 0,20 & 0,50 & 0,40 & 0,60 \\
\hline $\mathrm{FeO}$ & 17,50 & 15,80 & 18,10 & 14,80 & 15,60 & 12,80 \\
\hline $\mathrm{MgO}$ & 7,90 & 9,20 & 8,50 & 10,00 & 10,10 & 11,70 \\
\hline $\mathrm{CaO}$ & 15,80 & 16,50 & 16,40 & 14,70 & 15,70 & 17,60 \\
\hline $\mathrm{Na}_{2} \mathrm{O}$ & 5,10 & 4,60 & 5,00 & 4,40 & 4,30 & 3,30 \\
\hline $\mathrm{K}, \mathrm{O}$ & - & - & 0,03 & 0,03 & 0,02 & 0,03 \\
\hline $\mathrm{MnO}$ & 0,30 & 0,30 & 0,40 & 0,30 & 0,30 & 0,20 \\
\hline Total & 99,80 & 99.80 & 99,73 & 100,13 & 100,32 & 100,63 \\
\hline $\mathrm{Si}$ & 2,03 & 2,02 & 2,04 & 2,03 & 2,04 & 2,03 \\
\hline $\mathrm{Al}^{\mathrm{N}}$ & - & - & - & - & - & - \\
\hline SUM & 2.03 & 2,02 & 2,04 & 2,03 & 2,04 & 2,03 \\
\hline $\mathrm{Al}^{\mathrm{v}}$ & 0,03 & 0,02 & 0,01 & 0,02 & 0,02 & 0,02 \\
\hline $\mathrm{Fe}^{3+4}$ & 0,33 & 0,34 & 0,34 & 0,29 & 0,28 & 0,20 \\
\hline $\mathbf{T i}$ & 0,01 & 0,01 & 0,01 & 0,01 & 0,01 & 0,01 \\
\hline $\mathrm{Mg}$ & 0.46 & 0.53 & 0,49 & 0.57 & 0,57 & 0,65 \\
\hline $\mathrm{Fe}^{2+}$ & 0,17 & 0,10 & 0,15 & 0,11 & 0,12 & 0,12 \\
\hline SUM & 1,00 & 1,00 & 1,00 & 1,00 & 1,00 & 1,00 \\
\hline $\mathrm{Fe}^{2+}$ & 0,07 & 0,07 & 0,10 & 0,07 & 0,10 & 0,08 \\
\hline $\mathrm{Mn}$ & 0,01 & 0,01 & 0,01 & 0,01 & 0,01 & 0,01 \\
\hline $\mathrm{Ca}$ & 0,66 & 0,68 & 0,61 & 0,67 & 0,64 & 0.71 \\
\hline $\mathrm{Na}$ & 0,38 & 0.34 & 0,37 & 0,33 & 0,32 & 0,24 \\
\hline SUM & 1,12 & 1,10 & 1,09 & 1,08 & 1,07 & 1,04 \\
\hline
\end{tabular}

$\mathrm{TRF}=$ syenite $\mathrm{PTR}=$ pyroxene; $\mathrm{MTR}=$ mixed rock; $\mathrm{r}=$ rim; $\mathrm{c}=$ core

Table 2 - Representative chemical compositions and mineral formulae ofamphiboles of the Triunfo Batholith, northeastern Brazil. Proportions of ferric and ferrous iron were estimated based on the method by Robinson et al. (1982)

Tabela 2 - Composições químicas e fórmulas minerais representativas de anfibólios do Bató lito Triunfo, Nordeste do Brasil. Proporções de ferro (III) e ferro (II) foram estimadas com base no método de Robinson et al. (1982)

\begin{tabular}{|c|c|c|c|c|c|c|}
\hline \multirow{2}{*}{$\begin{array}{l}\text { sample } \\
\text { point }\end{array}$} & \multicolumn{2}{|c|}{ TRF $=28$} & \multicolumn{2}{|c|}{ PTR-28 } & \multicolumn{2}{|c|}{ MTR-28 } \\
\hline & $\mathbf{r}$ & c & $r$ & c & $\mathbf{r}$ & $\mathrm{c}$ \\
\hline $\mathrm{SiO}_{2}$ & 52.40 & 52.60 & 56.40 & 56.10 & 55.30 & 55.80 \\
\hline $\mathrm{TiO}_{2}$ & 0.70 & 0.80 & 0.04 & 0.06 & 0.20 & 0.20 \\
\hline $\mathrm{Al}_{2} \mathrm{O}_{3}$ & 1.80 & 1.60 & 0.20 & 0.20 & 0.60 & 0.50 \\
\hline $\mathrm{FeO}$ & 12.70 & 13.00 & 8.90 & 10.00 & 8.90 & 9.70 \\
\hline $\mathrm{MgO}$ & 16.00 & 15.50 & 18.70 & 17.60 & 18.30 & 18.00 \\
\hline $\mathrm{CaO}$ & 6.00 & 6.00 & 5.60 & 5.70 & 6.00 & 5.90 \\
\hline $\mathrm{Na}_{2} \mathrm{O}$ & 5.40 & 5.40 & 5.20 & 5.80 & 4.90 & 5.50 \\
\hline $\mathrm{K}_{2} \mathrm{O}$ & 2.60 & 2.30 & 1.70 & 1.50 & 2.30 & 2.20 \\
\hline $\mathrm{MnO}$ & 0.30 & 0.40 & 0.50 & 0.50 & 0.40 & 0.40 \\
\hline total & 97.90 & 97.60 & 97.24 & 97.46 & 96.90 & 98.20 \\
\hline $\mathrm{Si}$ & 7.66 & 7.69 & 8.05 & 8.04 & 7.95 & 7.96 \\
\hline $\mathrm{Al}^{\mathrm{N}}$ & 0.34 & 0.31 & - & - & 0.05 & 0.04 \\
\hline SUM & 8.00 & 8.00 & 8.05 & 8.04 & 8.00 & 8.00 \\
\hline$A l^{\mathrm{v}}$ & - & 0.01 & 0.04 & 0.03 & 0.06 & 0.05 \\
\hline $\mathrm{Cr}$ & - & 0.01 & 0.01 & - & 0.01 & - \\
\hline $\mathrm{Ti}$ & 0.07 & - & - & 0.01 & 0.02 & 0.02 \\
\hline $\mathrm{Fe}^{3+}$ & 0.08 & 0.13 & 0.23 & 0.27 & 0.28 & 0.11 \\
\hline $\mathrm{Mg}$ & 3.48 & 3.39 & 3.98 & 3.77 & 3.93 & 3.83 \\
\hline $\mathrm{Fe}^{2+}$ & 1.37 & 1.46 & 0.75 & 0.92 & 0.70 & 0.99 \\
\hline SUM & 5.00 & 5.00 & 5.00 & 5.00 & 5.00 & 5.00 \\
\hline $\mathrm{Fe}^{2+}$ & 0.11 & - & 0.08 & 0.01 & 0.09 & 0.05 \\
\hline Mn & 0.04 & 0.05 & 0.06 & 0.06 & - & 0.05 \\
\hline $\mathrm{Ca}$ & 0.94 & 0.94 & 0.85 & 0.88 & 0.93 & 0.91 \\
\hline $\mathrm{Na}$ & 0.91 & 1.01 & 1.01 & 1.05 & 0.98 & 0.99 \\
\hline SUM & 2.00 & 2.00 & 2.00 & 2.00 & 2.00 & 2.00 \\
\hline $\mathrm{Na}$ & 0.63 & 0.51 & 0.44 & 0.56 & 0.40 & 0.53 \\
\hline $\mathrm{K}$ & 0.48 & 0.43 & 0.30 & 0.28 & 0.42 & 0.40 \\
\hline SUM & 1.11 & 0.94 & 0.74 & 0.84 & 0.82 & 0.93 \\
\hline
\end{tabular}

$\mathrm{TRF}=$ syenite $\mathrm{PTR}=$ pyroxenite $\mathrm{MTR}=$ mixed rock; $\mathrm{r}=$ rim; $\mathrm{c}=$ core 
DISCUSSION AND CONCLUSION An important mineralogical consideration regarding unmixing process is that crystallizing phases in equilibrium with one liquid must also be in equilibrium with the other liquid phase

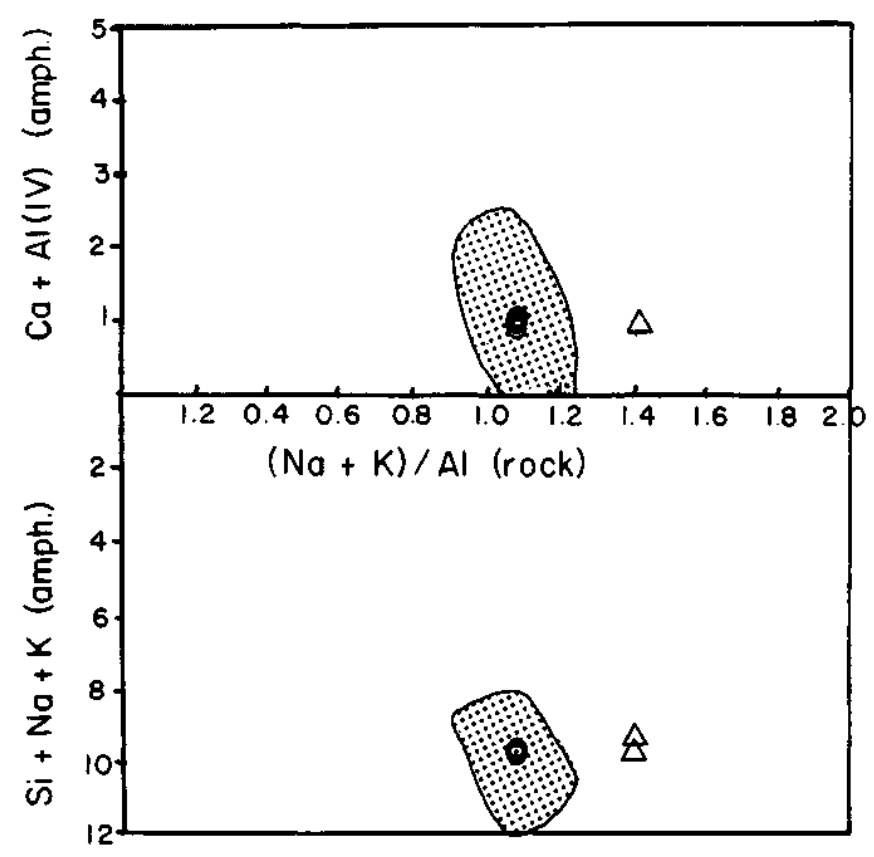

Figure 9 - Amphibole compositional variation in the Triunfo Batholith. (a) $\left(\mathrm{Ca}+\mathrm{Al}^{i v}\right)$ vs. agpaitic index of their host rocks. Field boundaries (stippled) for amphibole compositional trends in peralkaline syenites and granites according to Giret et al. (1980)

Figura 9 - Variação composicional de anfibólio no Batólito de Triunfo. (a) $\left(\mathrm{Ca}+\mathrm{Al}^{\mathrm{IV}}\right)$ vs. índice agpático das rochas contendo o anfibólio. Os campos para a variação composicional de anfibólios de sienitos e granitos peralcalinos são de Giret et al. (1980).
(Bowen 1928). In the Triunfo batholith, syenite and pyroxenite have the same mineral compositions, however, at different proportions.

Lack of significant compositional differences among pyroxene and amphibole of syenite and pyroxenite would not be expected if these rocks were related to each other by a simple fractional crystallization or partial melting process, or by mixing of unrelated magmas. The first two processes yield no compositional overlap between the same mineral phases in two coexisting magmas of contrasting compositions, as observed in the Triunfo pluton, although as a whole, a single compositional trend would be expected from early through late phases. On the other hand, overlap in pyroxene compositions is indicative of chemical equilibrium between the syenite and pyroxenite liquids, a behavior not expected if they were not genetically related to each other.

Although pyroxene crystals in the Triunfo Pluton are slightly zoned, it does not indicate that fractional crystallization has played a major role in the formation of these rocks. Because diffusion in melts is probably many orders of magnitude faster than in crystals, it is possible that a magma crystallized under fractionating, no equilibrium conditions, at the same time as the melt is splitting into two under equilibrium conditions (Roedder 1979).

The mafic mineral compositions of syenite and pyroxenite of the Triunfo batholith are compatible with the hypothesis of these two rock types constitute an immiscible pair.

Acknowledgments Field work was made possible by grants from the Brazilian Agencies FINEP/PADCT and CNPq. We are indebted to R.V. Fodor, North Carolina State University, Raleigh, North Carolina, USA, for his assistance during microprobe work. The manuscript was greatly improved by the comments of an anonymous reviewer. This is the contribution n. 62 of the NEG (Nucleus for Granite Studies, Dept. of Geology, Federal University of Pernambuco).
AFIFI, A.M. \& ESSENE, E.J. 1988. MINFILE: A microcomputer program for storage and manipulation of chemical data on minerals. Am. Mineral., 73:446-448.

ALBEE, A. L. \& RAY, L. 1970. Correction factors for electron probe microanalysis of silicates, oxides, carbonates, phosphates and sulfates. Anal. Chem., 42:1408-1414.

BARTON, M. 1979. A comparative study of some minerals occurring in the potassium-rich alkaline rocks of the Leucite Hills, Wyoming, the Vico volcano, Western Italy and the Toro-Ankole region, Uganda. N.Jb. Miner. Abh., 137(2): 113-134.

BENCE, A.F. \& ALBEE, A.L. 1968. Empirical correction for the electron probe microanalysis of silicates, oxides.J GeoL, 76:382-403.

BOWEN, N.L. 1928. The evolution of the igneous rocks. Princeton, Princeton Univ. Press. $332 \mathrm{p}$

DEER, W.A.; HOWIE, R.A.; ZUSSMAN, J. 1978. Rock-Forming Minerals. New York, Wiley \& Sons.

FERREIRA, V.P.; SIAL, A.N.; WHITNEY, J.A. 1992. Imiscibilidade de líquidos como o principal processo na formação de sienitos ultrapotássicos e piroxenitos associados, no Precambriano do Nordeste do Brasil. Anais Acad. bras. Cien., 64(4):367-382

GIRET, A.; BONIN, B.; LEGER, J.M. 1980. Amphibole compositional trends in oversaturated and undersaturated, alkaline plutonic ring complexes. Can. Mineral., 18:481-495.

GOMES, C.B.; MORO, S.L.; DUTRA, C.V. 1970. Pyroxenes from the alkaline rocks of Itapirapua, São Paulo, Brazil. Am. Mineral., 55:224-230.
LEAKE, B.E. 1978. Nomenclature of amphiboles. Can. Mineral., 16:501520.

LINDSLEY, D.H. \& ANDERSON, D.J. 1983. A two pyroxene thermometer. J. Geophys. Res., 88(suppl.A):887-906.

MORIMOTO, N. (Chairman) 1988. Nomenclature of pyroxenes. Mineral. Mag., 52:535-550

PLATT.R.G. \& WOOLEY, A.R. 1986. The mafic mineralogy of the peralkalic syenites and granites of the Mulanje complex, Malawi. Min.Mag., 50:85-99.

RAHMAN, S. 1975. Some aluminous clinopyroxenes from Vesuvius and Monte Somma, Italy. Mineral. Mag., 40:43-52.

ROBINSON, P.; SPEAR, F.S.; SCHUMACHER, J.C.; LAIRD, J.; KLEIN, C.; EVANS, B.W.; DOOLAN, B.L. 1982. Phase relations of metamorphic amphiboles: natural occurrence and theory. In: VEBLEN, D.R. \& RIBBE, P. H. eds. Amphiboles: Petrology and Experimental Phase Relations. Chelsea, Mineral. Soc. Amer. (Reviews Mineral. 9B).

ROEDDER, E. 1979. Silicate liquid immiscibility in magmas. In: Yoder, H.S. ed. The Evolution of the Igneous Rocks. $50^{\text {th }}$ Anniversary Perspectives. Princeton, Princeton Univ. Press. 588 p.

MANUSCRITOA770 Recebido em 30 de marco de 1993 Revisao do autor em 23 de abril de 1993 Revisao aceita em 5 de maio de 1993 